\title{
AN ANALYSIS OF THE CONSTITUTIONAL COURT RULING ON THE ANNULMENT OF THE PROVISIONS ON COASTAL WATER CONCESSIONS (HP-3)
}

\author{
M. Riza Damanik ${ }^{1}$
}

\begin{abstract}
After the annulment of the Coastal Water Concessions (HP-3) in 16 June 2011, traditional fisher folk organization leaders found a great fighting spirit to further follow-up the Constitutional Court Ruling to support their daily lives.

For those who are being "evicted" from their living space (the coastal waters), they want to reclaim their rights through constitutional ways. Likewise, those who (feel to) have lost their existence as Indonesian traditional fisher folk are impatient to find out whether there is a breakthrough in the Constitutional Court Ruling that can restore the fisher folk's family way of life. The ruling itself was complex and not easy to understand: 169 pages, with complex writing systematic and typical legal language.

For this reason, the analysis of the Constitutional Court Ruling regarding the Judicial Review on Law No. 27 of 2007 on the Management of Coastal Areas and Small Islands was necessary in order to provide a simpler representation of the Constitutional Court Ruling, and one that is expected to trigger a constructive discussion to implement the favorable parts of the decree for the greatest welfare of the people.
\end{abstract}

\section{Keywords :}

\section{Introduction}

Afterapproximately 13 years of direct involvement in marine and fishery issues, there are differences over the last four years. First, the aggressiveness of the fisher folk to seek out and study various policies and programs related to fishery is relatively high compared to previous years. Thus, a strong fisher folk organization: organized, educated, and independent-is one step closer to being realized.

Second, the public involvement and attention-both for and against-from government officials, members of the House of Representatives (DPR RI), politicians, academics, university students, legal practitioners, NGOs, cultural communities, and the public in general on discussing various government policies and programs in the scope of the sea and fishery is increasing. It is indicated by the mainstreaming of political waves, not only at the local, national, but also at the global forums that is urging for the realization of fishery justice

1 Executive Director of Indonesia for Global Justice (IGJ); Applicant I of Judicial Review of Law No. 27 Year 2007. The author can be contacted at riza.damanik@gmail.com. 
in a diversity of perspectives.

At this moment, after the Constitutional Court Ruling annulling the articles related to Coastal Water Concessions (HP-3), Thursday, June 16, 2011, I have again found both. In North Sulawesi, Tuesday, June 21, 2011, in the presence of a number of traditional fisher folk organization leaders, I found a great fighting spirit to further follow-up the Constitutional Court Ruling in the fisher folk's daily lives.

For those who are being "evicted" from their living space (the coastal waters), they want to reclaim their rights through constitutional ways. Likewise, those who (feel to) have lost their existence as Indonesian traditional fisher folk are impatient to find out whether there is a breakthrough in the Constitutional Court Ruling that can restore the fisher folk's family way of life. At the same time, the general public, both (initially) for or against the HP-3, is interested to study in-depth the Constitutional Court Ruling that took a trial time of more than 1 year and 5 months.

All of them expect a simple document of analysis of the Constitutional Court Ruling: containing 169 pages, with a complex writing systematic and typical legal language.

For this reason, the analysis of the Constitutional Court Ruling regarding the Judicial Review on Law No. 27 of 2007 on the Management of Coastal Areas and Small Islands was necessary in order to provide a simpler representation of the Constitutional Court Ruling, and one that is expected to trigger a constructive discussion to implement the favorable parts of the decree for the greatest welfare of the people.

\section{HP-3 at a Glance}

On June 26, 2007, in its Plenary Session, the DPR RI passed the Law No. 27 of 2007 on the Management of Coastal Areas and Small Islands (MCASI). It is said that the idea was to make it a breakthrough to resolve the conflict of laws which had (previously) regulated coastal water areas and small islands, including to bridge the state's intent to protect the interests of fisher folk families and indigenous peoples. It is assumed that, by the presence of such laws, the development of coastal areas and small islands can move toward the maximum.

Procedurally, the preparation of the Law Draft (RUU) of MCASI took a long time and involved a number of parties, including foreign ones; it took more than seven years to pass this legislation, beginning with the drafting of an Academic Paper at the second half of the year 2000, which involved academics, legal practitioners, NGOs, and input from a number of foreign experts, mainly from Rhode Island University and a number of public policy activists from the United States.

Similarly, in terms of funding, aside from utilizing state budget allocations, the initiation, formulation, and up to the socialization phases of the MCASI Law was known to also involve a series of foreign funding, directly or indirectly, such as from the U.S. Agency for International Development (USAID), and including foreign debts to the Asian Development Bank (ADB) and World Bank. 
Unfortunately, although it involved a number of experts in the field of the management of coastal areas and small islands, the Law Number 27 of 2007 on the Management of Coastal Areas and Small Islands has not actually used the Integrated Coastal Management approach. This is marked by the failure to correct: inequality of control and concession of coastal and small islands resources, as well as the growing complexity of overlapping legislations governing the areas.

The Law No. 27 of 2007 also puts more emphasis on the investment aspect and is more pro-business, leaving no room for the community, particularly the traditional fisher folk and indigenous peoples, to propose a management plan. Furthermore, the Law of MCASI effectively relegates the matter of the territorial sovereignty of Republic of Indonesia (NKRI) only to the level of a Government Regulation.

In the Law of MCASI, Coastal Waters Concessions (HP3) are regulated. It can be stated the HP-3 is the "heart" of the this law. HP3 is an instrument that certifies the concession of coastal waters and small islands, for aquaculture, tourism, and mining, to the private sector, including of foreign origin.

In more detail, the objects of marine concessions are the water surface, column, down to the floor with a concession period of an accumulated 60 years. Moreover, it can transfer or be transferred and be used as debt collateral by applying mortgage rights.

Thus, the substance of HP-3 would certainly legalize the revocation of rights of fisher folk families, indigenous peoples and coastal communities in accessing resources in either coastal, marine or small island areas. All access to coastal and small islands resources are open to be controlled by the capital owners since only they (investors/capital owners) are able to meet all the requirements stipulated in the Law to obtain HP-3 certificate, namely: administrative, technical, and operational requirements.

Coastal communities will potentially just be spectators because they do not have the capacity (capital, knowledge, access to information and technology) to compete with capital owners. In the end, there will be no more space left for coastal communities, particularly fisher folk, cultivators, fisher folk workers to conduct social, economic and cultural activities in coastal and small islands areas. All are potentially exacerbating the strain poverty on fisher folk family.

Broadly speaking, Law of MCASI left a number of issues, among others are first, the Law No. 27 of 2007 has always been linked to adaptation to global situations. It is unclear as to what global context is meant. However, dissecting it deeper, the global concept here is more about globalization.Second, problems arising from privatization in the realm that should be controlled by the state as well as issues of zoning; third, the weakened protection of vulnerable groups in coastal rural areas; fourth, the problems of poverty and the threat to sovereignty in small island states; fifth, disharmony of the MCASI Law with other related legislations regarding coastal areas management.

Therefore, the "Reject HP-3" Coalition which consists of nine civil society organizations, and 27 head of fisher folk organizations, on 13 January 2010, jointly filed a petition for the Judicial Review of Law No. 27 of 2007, mainly the articles related to HP-3, to the Constitutional Court. 
Table 1. List of Petitioners for Judicial Review of Law Number 27 of 2007

\begin{tabular}{|c|c|c|c|}
\hline No & Organizations & No & Fisher folk \\
\hline 1 & $\begin{array}{l}\text { Koalisi Rakyat untukKeadilanPerikanan } \\
\text { represented by M Riza AdhaDamanik }\end{array}$ & 1 & Tiharom \\
\hline 2 & $\begin{array}{l}\text { Indonesian Human Right Committee for Social Justice } \\
\text { (IHCS) represented by Gunawan }\end{array}$ & 2 & Waun \\
\hline 3 & $\begin{array}{l}\text { PusatKajianPembangunanKelautandanPeradabanMaritim } \\
\text { (PK2PM) represented by MuhamadKarim }\end{array}$ & 3 & Wartaka \\
\hline 4 & $\begin{array}{l}\text { KonsorsiumPembaruanAgraria (KPA) represented by } \\
\text { IdhamArsyad }\end{array}$ & 4 & Carya Bin Darja \\
\hline 5 & $\begin{array}{l}\text { SerikatPetani Indonesia (SPI) represented by Henry } \\
\text { Saragih }\end{array}$ & 5 & Kadma \\
\hline 6 & YayasanBinaDesaSadajiwa represented by DwiAstuti & 6 & Saidin \\
\hline 7 & $\begin{array}{l}\text { YayasanLembagaBantuanHukum Indonesia } \\
\text { represented by PatraMijayaZein; }\end{array}$ & 7 & Jamhuri \\
\hline 8 & $\begin{array}{l}\text { WahanaLingkunganHidup Indonesia (WALHI) represented } \\
\text { by Berry NahdianForqan }\end{array}$ & 8 & Rosad \\
\hline \multirow[t]{19}{*}{9} & $\begin{array}{l}\text { AliansiPetani Indonesia (API) represented by Muhammad } \\
\text { NurUddin }\end{array}$ & 9 & Tarwan \\
\hline & & 10 & Tambrin Bin Tarsum \\
\hline & & 11 & Yusup \\
\hline & & 12 & Rawa Bin Caslani \\
\hline & & 13 & Kasirin \\
\hline & & 14 & Salim \\
\hline & & 15 & Warta \\
\hline & & 16 & Rakim Bin Taip \\
\hline & & 17 & Kadim \\
\hline & & 18 & Abdul Wahab Bin Kasda \\
\hline & & 19 & Mujahidin \\
\hline & & 20 & Kusnan \\
\hline & & 21 & Caslan Bin Rasita \\
\hline & & 22 & Kartim \\
\hline & & 23 & Rastono Bin Cartib \\
\hline & & 24 & Ratib Bin Takrib \\
\hline & & 25 & Wardi \\
\hline & & 26 & Andi Sugandi \\
\hline & & 27 & Budi Laksana \\
\hline
\end{tabular}

\section{Substance Of The Claim By The “Reject Hp-3” Coalition}

Substantially, there are seven main ideas that underlie efforts to Judicial Review of Law Number 27 of 2007 on the Management of Coastal Areas and 
Small Islands by the Reject HP-3 Coalition.

1. Article 1 number $4^{2}$, number $7^{3}$ and number $18^{4}$, article 16 paragraph $(1)^{5}$, article 23 paragraph $(2)^{6}$ and paragraph (4) ${ }^{7}$ Law No. 27 of 2007 as an explanation of the HP-3 objects overlapped with other laws and caused legal uncertainty and are contradictory to article 28D paragraph (1) of the 1945 Constitution;

2. Article 1 number 18 of Law No. 27 of 2007 that governs the concept of HP3 are contrary to article 33 paragraph (2) and paragraph (3) of the 1945 Constitution;

3. Article 14 paragraph $(1)^{8}$ of Law No. 27 of 2007 is contrary to article 1 paragraph (3), article 28A, article 28D paragraph (1), article 28I paragraph (2) and article 33 paragraph (3) of the 1945 Constitution.

4. Article 16 paragraph (1) and paragraph (2) ${ }^{9}$ of Law No. 27 of 2007 on HP-3 are contradictory to article 18B paragraph (2) of the 1945 Constitution, article 28A of the 1945 Constitution and article 33 paragraph (1) and paragraph (3) of the 1945 Constitution.

5. Article 20 paragraph $(1)^{10}$ of Law No. 27 of 2007 which allows HP-3 to be an object of mortgage is contrary to article 33 paragraph (3) of the 1945 Constitution.

${ }^{2}$ Coastal and Small Islands Resources are the biological, non-biological resources; artificial resources, and environmental services; biological resources include fish, coral reefs, seagrass beds, mangroves and other marine biota; non-biological resources includesand, sea, seabed minerals; artificial resources including marine infrastructure related to marine and fisheries, and environmental services of natural beauty, the sea floorsurface for underwater installationsrelated with marine and fisheries also ocean wave energy contained in Coastal Areas.

${ }^{3}$ Coastal waters are marine waters adjacent to land covering as far as 12 nautical miles from the coastline, the waters linking the shore and islands, estuary, bay, shallow waters, brackish marshes, and lagoons.

${ }^{4}$ Coastal Waters Concessions, hereinafter referred to as HP-3, is the right over certain parts of the coastal waters for marine and fishery business, as well as other businesses associated with the utilization of Coastal Areas and Small IslandsResources that covers the sea surface and water column down to the surface of the seafloor to a certain limited extent.

${ }^{5}$ The utilization of coastal waters is given in the form of HP-3.

${ }^{6}$ The utilization of Small Islands and surrounding waters is prioritized for one or more of the following interests: a. conservation; b. education and training; c. research and development; d. marineculture; e. tourism; f. fisheries and maritime affairs also fisheries industries in a sustainable manner; g. organic farming; and/or h. farms.

7 The utilization of Small Islands and surrounding waters referred to in paragraph (2) and meet the requirements in paragraph (3) shall have HP-3 issued by the Government or Local Government in accordance with their authority.

8 The proposed Strategic Plan for Coastal Areas and Small Islands (RSWP-3-K), the Zoning Plan of Coastal Areas and Small Islands (RZWP-3-K), Management Plan of Coastal Areas and Small Islands (RPWP3- K), and the Action Plan for Management of Coastal Areas and Small Islands (RAPWP-3-K) is formulated by the Local Government and the private sector.

${ }^{9}$ The HP-3 as referred to in paragraph (1) includes the management of the sea surface and water column up to the surface of the sea floor.

${ }^{10}$ The HP-3 can transfer, be transferred, and registered as collateral by applying mortgage. 
6. Article 23 paragraph (4), paragraph (5) $)^{11}$, and paragraph (6) ${ }^{12}$ of Law No. 27 of 2007 that requires the utilization of small islands and surrounding waters to possess HP-3 issued by the government or local government are contrary to article $18 \mathrm{~B}(2)$, article $28 \mathrm{C}$ paragraph (2), and article $28 \mathrm{H}$ paragraph (2) of the 1945 Constitution.

7. Article 60 paragraph (1) letter $b^{13}$ Law Number 27 Year 2007 is contradictory to article 28A, article 28E paragraph (1) and paragraph (2) and article 28G paragraph (1) of the 1945 Constitution.

\section{Analysis of The Constitutional Court Ruling}

As already set out in the Constitutional Court Ruling before, there were two constitutional matters that must be addressed by the Court, namely:

1.Does the issuance of HP-3 contradictory to the principle of state control over natural resources for the greatest welfare of the people, the constitutional guarantee of the right to life and sustained livelihood of coastal communities, the principles of non-discrimination and a just legal certainty as argued by the Reject HP-3 Coalition?;

2. Does the drafting of RSWP-3-K, RZWP-3-K, RPWP-3-K, RAPWP-3-K that does not place the communities as participants to the consultation violate the constitutional rights of Petitioners (Reject HP-3 Coalition) and can be found unconstitution?.

Related to both questions above, the Constitutional Court gave the following explanations:

1. With the phrase "utilized for the greatest welfare of the people" in Article 33 paragraph (3) of the 1945 Constitution, then the greatest welfare of the people is the primary measure for the state in determining administration, regulation or management of land, water, and natural resources contained therein.

2. The control by State over earth, water and natural resources contained therein shall also consider the prevailing rights, both individual and collective, of peoples adhering to traditional law (hakulayat), the rights of indigenous peoples and other constitutional rights entitled to the people and guaranteed by the constitution, such as access right to cross, right to a healthy environment, and others.

3. HP-3 will result in the loss of indigenous/traditional peoples' rights which has been passed down through the generations. However, these rights have certain characteristics, which is that they cannot be eliminated as long as the indigenous communities exist.

4. HP-3 will result in the elimination of indigenous/traditional people in ob-

\footnotetext{
${ }^{11}$ For the utilization of small islands and surrounding watersthat have been used for the benefit of
} livelihood of the Community, the Government or Local Government issues HP-3 after consultating with the impacted communities.

${ }^{12}$ Regent/Mayor facilitatesthe consultation mechanism referred to in paragraph (5).

13 ... obtaincompensation for the loss of access to the Coastal and Small Islands Resources that has been the livelihood to fulfill the needs as a result of HP-3 granting in accordance with the legislation. 
taining HP-3 due to lack of capital, technology and knowledge, while in fact, the state, in this case the government, is obligated to promote the general welfare and social justice for all Indonesian people [see the fourth paragraph of the Preamble of the 1945 Constitution and Article 34 paragraph (2) 1945 Constitution].

5. The purpose of this legislation is in order to legalize the division of coastal regions and small islands into lots to be made the private and close ownership of individual, legal entities or certain members of society, so that the largest part of the management of coastal areas and small islands is left to the individual, legal entities, and community groups as set out in Law No. 27 of 2007 by granting HP-3. This means that there is a spirit of privatization of the management and utilization of coastal waters and small islands to businesses and private individuals.

In line with the above explanation, the Constitutional Court states: Article 1 number 18, Article 16, Article 17, Article 18, Article 19, Article 20, Article 21, Article 22, Article 23 paragraph (4) and paragraph (5), Article 50, Article 51, Article 60 paragraph (1), Article $71^{14}$ and Article $75^{15}$ of Law Number 27 of 2007 on the Management of Coastal Areas and Small Islands (State Gazette of the Republic of Indonesia Year 2007 Number 84, Supplementary State Gazette of the Republic of Indonesia Number 4739) to be in contrary to the Constitution of the Republic of Indonesia Year of 1945 and to have no binding legal effect.

Or, in other words the entire articles related to HP-3, including Article 71 and 75 that have not been requested by the Petitioners to be reviewed, are declared unconstitutional and void.

\section{Breakthroughs by The Constitutional Court}

In examining the ruling document, which is 169 pages thick, there are at least three breakthroughs by the Constitutional Court, not only internally, to strengthen the struggle of fisher folk communities and indigenous peoples, but also the externally, to clarify the constitutional interpretation of a number of legislation both in national and sub-national level.

Externally, in assessing how far does the granting of HP-3 provide a benefit for the greatest welfare of the people, the Constitutional Court used the following benchmarks, namely:

(i) the benefit of natural resources for the people;

(ii)the level of distribution of benefit of natural resources for the people;

(iii)the level of public participation in determining the benefit of natural resources, and;

${ }^{14}$ Paragraph (1) Violation to the requirements as stated in HP-3 is subject to administrative sanction. Paragraph (2) Administrative sanctions as referred to in paragraph (1) are as follows: a warning, temporary suspension, administrative fine, and/or revocation of HP-3. Paragraph (3) Further provisions on administrative fines as referred to in paragraph (2) is regulated by the Minister Regulation.

15 Shall be punished with imprisonment of 6 ( $\mathrm{six}$ ) months or penalties of not more than Rp. 300.000.000,00 (three hundred million rupiah) per person due to negligence: (a) conducts business in Coastal Areas without HP-3 as stipulated n Article 21 paragraph (1); and/or (b) does not implement obligation as stipulated in Article 21 paragraph (4). 
(iv)the respect for people's rights from generation to generation in utilizing natural resources.

By using these four indicators, the Constitutional Court ruled that HP-3 to be contrary to the Constitution. Or in other words, granting HP-3 cannot provide (the guarantee of) the utilization of coastal waters and small islands resources for the greatest welfare of the people.

These four indicators can be used not only to measure the constitutionality of HP-3, but also to measure the constitutionality of the other legislations (national and sub-national) related to the management of natural resources and environment of Indonesia, for instance, Plantation Law, Mineral and Coal Law, Fisheries Law, and so on.

Thus, the Constitutional Court in its ruling of HP-3 have also provided a significant external contribution, i.e. asserting and providing a constitutional measuring instrument to the meaning of "for the greatest welfare of the people".

Internally, the Constitutional Court Ruling acknowledged and affirmed the existence of traditional fisher folk (once again, the traditional fisher folk)not small fishers, as found in Law Number 45 of 2009 on Fisheries, which is a wrong identification and on that is biased towards economic and technology interests. As "small fishers" (referring to Law Number 45 of 2009 on Fisheries) they are categorized only by vessel weight and technology, and the economic capacity bracket they are in. As a result, aspects of traditional culture and wisdom, which in essence is the guide for the fisher folk communities to manage fisheries and marine resources fairly and sustainably has been disregarded.

Accordingly, the Constitutional Court has indirectly set out the constitutional rights of traditional fisher folk, among them: the rights to pass (access); the right to manage resources in accordance with cultural principles and traditional wisdom assumed and passed down for generations; the right to exploit resources, including, the rights to a healthy and clean water environment. All of which are inherent in the individual or collective of the traditional fisher folk and should not be exchanged.

As far as my understanding in following and studying the policy discourse on fisheries and fisher folk issues in Indonesia, this is the first affirmation of the existence of Indonesian traditional fisher folk, including their constitutional rights embodied in a state gazette. Therefore, it seems appropriate that the term "small fishers" in the Fishery Law be corrected. This includes mainstreaming the fulfillment of the constitutional rights of traditional fisher folk in all government policies and programs.

\section{Ambiguity of Court Ruling}

Although the annulment of HP-3 articles has been declared by the nine Constitutional Court Judges, and a number of breakthroughs with regards to fisher folk affairs and HP-3, the Constitutional Court Ruling also left a number of issues unaddressed.

First, on the status of Article 14. Although the Constitutional Court has given its legal consideration on Article 14 paragraph (1), as follows: Article 14 paragraph (1) leads to the practice of silencing the right of people to participate and to submit a proposal that the people then have no option to reject or 
accept the plan (the proposal for RSWP-3-K, RZWP-3-K, RPWP-3-K, and RAPWP-3-K) and when a policy is not based on public participation, it potentially causes violations of public rights at a later time, disregarding the people's rights over their territories, even though it is them that know and understand the condition of the area.

According to the Court, the submission of proposals which only involves the government and private sector is a form of unequal treatment amongst citizens and it does ignore the rights of the communities to advance themselves and struggle for their rights collectively to build the communities, nation, and the country. This is contradictory to the Article 27, Article 28C Paragraph (2), and Article 28D Paragraph (3) of the 1945 Constitution.

However, in the verdict, the Constitutional Court did not include/mention Article 14 (as requested by the Applicant) to be contrary to the 1945 Constitution and null and void.Therefore, in this matter, the Constitutional Court can be considered as being technically less than thorough, although in its legal considerations, the constitutionality status of Article 14 is clear enough-that is contrary to the 1945 Constitution.

Second, regarding the views of the Constitutional Court that states: “... to avoid the transfer of state control responsibility over the management of coastal waters and small islands to the private sector, the state can provide that management rights through licensing mechanism."

Some, mainly from the government, read the views of the Constitutional Court separately, and not the entire of the petition for Judicial Review filed by the Reject HP-3 Coalition, which has been granted in the end by the Constitutional Court with the annulment of the articles related to HP-3.

When examined as a whole, then the process of Judicial Review of Law Number 27 of 2007 on the Management of Coastal Areas related to articles of HP-3 is not just in the context of legal structure, but one that replaces the term "rights" for Coastal Water Concession Rights, to "permit". Moreover, it ensured the utilization of the earth, water, and natural resources contained therein for the greatest welfare of the people, not the private sector, let alone foreign ones. It then confirmed the recognition and respect for the unit of indigenous peoples and their traditional rights, and to uphold social justice for all Indonesian people, including the fisher folk family.

Thus, the Constitutional Court's opinion regarding the entitlement of management and utilization rights of coastal and small islands resources through licensing mechanism in the future must not disregard its opinion regarding the benchmark of the greatest welfare of the people; recognition of and respect for indigenous peoples and their traditional rights, and also, the realization of social justice for all Indonesian people, including the fisher folk family.

Third, on the status of the Constitutional Court Ruling which applies only to the future (prospective, not retroactive). It is certainly possible to be debated. Evenmore after the Constitutional Court Ruling to annul the articles of HP-3 are absolute with the elaboration of legal considerations which are clear and complete.

Related to this, the government should disclose license status information that has been granted for the management and utilization of coastal and small islands resources to the private sector, including foreign ones. This is necessary so that the various public loss, as defined by the Constitutional 
Court in its decree, is not widespread and could be resolved as soon as possible.

\section{Recommendations and Proposed Follow-Up (Agenda)}

With the Constitutional Court Ruling on the Judicial Review of Law No. 27 of 2007, there is a hope for the restitution of the constitutional rights of traditional fisher folk families, indigenous people and coastal communities. Consequently, it requires the collective compliance to the ruling for the greatest welfare of the people!

First, philosophically, in optimizing the role of the marine and fisheries sector, by constituting a particular Ministry of Marine Affairs and Fisheries over the one last decade, must not only just move the economic coffers that is almost "broke" from land to the sea. Moreover, the ruling of the Constitutional Court Ruling has affirmed that the policy of privatization of coastal waters and small islands is an action that violates the constitution.

Second, technically, the government and Parliament need to revise all rules, both national and sub-national, which retains the spirit of management and privatization similar to HP-3, including "to clean" areas of coastal, marine, and small islands from various forms of impoverishing commercialization. In North Sumatra, for example, there has been a Local Regulation No. 5 Year 2008 on the Management of Coastal Areas and Small Islands in which clearly states Coastal Water Concessions.

At this stage, the consolidation of multi-sectors civil society needs to be enhanced to campaign the success of the fisher folk organizations in guarding the constitution, while inspiring similar victories in other strategic sectors, including to speed up the process of annulment of the Local Regulation and Drafts of Local Regulations in their respective areas.

Third, operationally, the state must restore the constitutional rights of fisher folk citizens: the right to pass (access), right to manage resources in accordance with the principles of traditional culture and wisdom that is assumed and carried out for generations; the right to utilize resources, including ensuring that no more contaminants flushed into the sea, the living space and source of livelihood of fisher folk. Because in fact, the overall annulment of HP-3 is a conscious effort to help the Indonesian people (traditional fisher folk families and indigenous peoples) to come out from the crushing pressure of poverty that is growing worse. At the same time, saving the dignity of the state apparatus by preventing them from exercising misguided policies that are contradictory to the constitution.

In line with the above, the decision of DPR RI to include the draft Law of Fisher folkProtection into the National Legislation Program (Prolegnas) of 2009-2014 should be followed up by ensuring the full involvement of traditionalfisher folk and indigenous peoples organizations in the drafting of the bill.

All of them need to be conducted in a not too long of a time so that the management and utilization of coastal and small islands resources can be beneficial for the greatest welfare of the people, while at the same time not colliding with the 1945 Constitution. 